\title{
FACTOR AFFECTING BUSINESS SUSTAINABILITY OF SMALL AND MEDIUM COFFEE SHOP
}

\section{FAKTOR YANG MEMPENGARUHI KEBERLANJUTAN USAHA KEDAI KOPI KECIL DAN MENENGAH}

\author{
Binagusto Mochammad"), Mukhamad Najib, and Mochammad Mukti Ali \\ Department of Management Business, School of Business, IPB University \\ Jl. Pajajaran, SB-IPB Gunung Gede, Bogor 16128, Indonesia \\ *E-mail: gustom07@gmail.com
}

Makalah: Diterima 09 September 2020; Diperbaiki 28 November 2020; Disetujui 08 Desember 2020

\begin{abstract}
ABSTRAK
Penelitian ini bertujuan untuk mengetahui faktor-faktor yang mempengaruhi keberlangsungan kedai kopi bagi usaha kecil dan menengah (UKM) di Bogor. Jumlah kedai kopi mencapai lebih dari 90 gerai pada tahun 2019 dan banyak diantara mereka yang terpaksa menutup usahanya pada tahun berikutnya. Hal ini disebabkan oleh ketidakmampuan dari kedai kopi mandiri untuk memiliki sistem operasional yang baik. Faktor-faktor yang diamati dalam penelitian ini adalah manajerial, pelayanan, produk, ukuran perusahaan, dan lingkungan. Metode yang digunakan dalam penelitian ini adalah pengambilan data dengan menggunakan kuesioner dan wawancara. Responden terdiri atas 65 pengelola dan pemilik warung kopi mandiri di Bogor yang telah berumur lebih dari 1 tahun. Data yang telah diperoleh diolah menggunakan SEM PLS. Hasil penelitian ini menunjukkan bahwa manajerial, produk, dan layanan merupakan faktor yang secara signifikan mempengaruhi keberlangsungan usaha warung kopi mandiri secara positif. Sementara itu faktor ukuran perusahaan dan lingkungan tidak berpengaruh terhadap keberlanjutan dari kedai kopi mandiri. Selain itu diketahui dari penelitian ini bahwa faktor servis memediasi hubungan antara manajerial dan keberlanjutan secara signifikan dan positif. Dari sisi konsumen, pemilik harus memberikan pengalaman yang baik kepada konsumen agar konsumen dapat mencapai kepuasan.
\end{abstract}

Kata kunci: bisnis UKM, faktor internal, keberlanjutan, kedai kopi mandiri, SEM PLS

\section{ABSTRACT}

This research aimed to determine the factors that influence the sustainability of the coffee shop for small and medium enterprises (SMEs) in Bogor. The number of coffee shops reached more than 90 stores in 2019 and many of them were forced to close their businesses in the following year. This was due to the inability of independent coffee shops to have a good operational system. The factors observed in this research were managerial, service, product, company size, and environment. The method used in this study was to take data using questionnaires and interviews. The respondents consisted of 65 managers and independent coffee shop owners in Bogor that opened their business for more than one year. The data obtained was processed using SEM PLS. The results of this study indicate that managerial, product, and service are factors that significantly and positively influence the sustainability of the independent coffee shop business. Meanwhile, company size and environmental factors have no effect on the sustainability of the independent coffee shop. In addition, it is known from this study that the service factor significantly and positively mediates the relationship between managerial and sustainability. From the consumer side, the owner must provide a good experience to consumers so that consumers can achieve satisfaction.

Keywords: independent coffee shop, internal factor, SME business, sustainability, SEM PLS,

\section{INTRODUCTION}

The SME sector has played an important role in economic development, poverty alleviation, and employment in developing countries (Tarute and Gatautis, 2014). SMEs are a key point for employment, development and commercialization of innovations and the means to advance the competitiveness of global markets (Mazzarol et al., 2014). In the context of developing countries, with regard to Indonesia, which is a developing country, SMEs contribute more than 95 percent of all businesses (Rahayu and Day, 2015). SME is one of the important economic factors in Indonesia, contributing more than $50 \%$ of GDP and absorbing $97 \%$ of workers. However, with the emergence of the global market trend, it is experiencing competition from imported foreign goods (Irjayanti and Aziz, 2012).

Bogor is one of the cities whose economy is supported by SMEs. SME contributes $70 \%$ of the local revenue of the Bogor City. SME in the Bogor City reached 13,953 in 2019 (Ramdhani and Hardjomidjojo, 2019). According to the results of research conducted by Ramdhani and Hardjomidjojo (2019), index sustainability of Bogor City SME

*Coressponding Author 
reached the value of 49.8 , which is included in the developed category.

Figure 1 showed that from 2015 to 2018, the total consumption of coffee in Indonesia is more than $1,125,000$ tons (ICO, 2019). The high level of coffee production in Indonesia can be seen in Figure 2. The data showed that in 2015 to 2018 with total production reaching $2,663,760$ tons, making Indonesia the 4th largest coffee producing country in the world after Brazil, Vietnam, and Colombia. The Indonesian agricultural sector contributes $12.08 \%$ of Indonesia's GDP in 2018 (ICO, 2019). The decrease in Indonesian coffee production in was caused by the decrease in coffee agricultural land and unstable climate in Indonesia last 5 years (BPS, 2019).

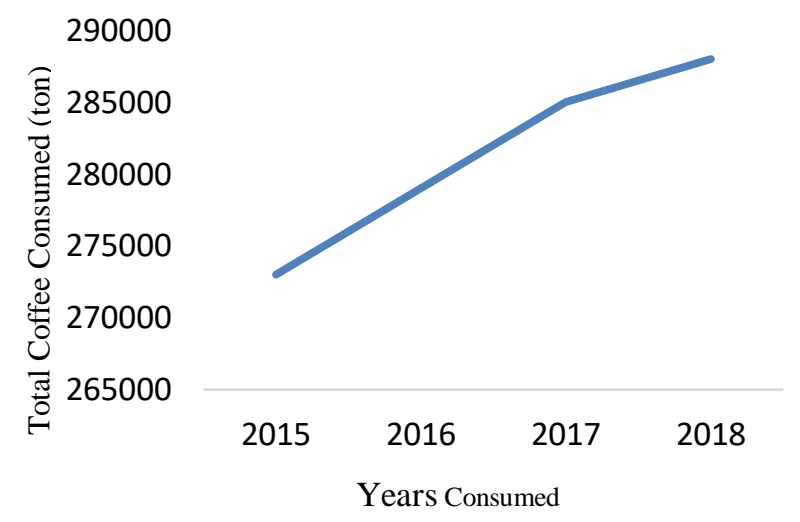

Figure 1. Total coffee consumed in Indonesia (ICO, 2019)

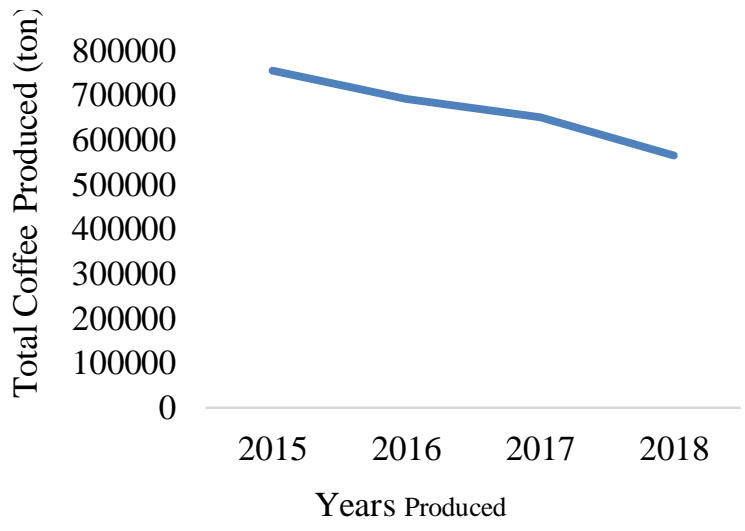

Figure 2. Total coffee produced in Indonesia (ICO, 2019)

Chairman of Indonesian Specialty Coffee said there was no data on the number of coffee shops in Indonesia, but growth in 2019 would reach $15 \%$ $20 \%$ (Zuhriyah, 2019). However, the existence of very rapid growth will also result in many failures being diverted by coffee shops in the first five years. The food truck empire survey agency collects data on the number of coffee shops that fail. The results of a survey conducted showed that 50\% -74\% coffee shops will fail at the age of less than five years. Based on research by Higdon (2016), successful independent coffee shop is a coffee shop that can last more than 5 years. The common problem of independent coffee shop that cannot generate fast consumer appeal may fail to survive during the first five years (Nadiri and Guna, 2013). For every business that started in 2011, a 2-year survival rate is $75 \%$, with a 3 -year survival rate of $60 \%$ and a 4 -year survival rate of $49 \%$ and a 5-year survival rate of $44 \%$. However, in the accommodation and food services sector only $34.6 \%$ of businesses last 5 years. Independent coffee shops have become popular SME in Indonesia. The level of coffee shop competition in the city of Bogor is getting higher. The number of coffee shops reached more than 90 stores in 2019. The high level of competition requires coffee shops to prepare strategies to sustain. The strategy used is not only to attract consumers and increase sales, but must be balanced with careful operational preparation, as independent coffee shops are more likely to fail during their first year than franchise coffee shops due to poor operating systems. Coffee shops are commercially managed businesses that offer guests a variety of coffee and snack menus (Susanty and Kenny, 2015). The definition of an independent coffee shop is a business in the field of food and beverages that is managed directly by the owner of the coffee shop. Independent coffee shops are in demand by the community to become a business or main livelihood.

Throughout the life cycle, the first year is the most vulnerable for new businesses to close. Previous research has found that over the years, failure rates tend to fall, and in the fourth, fifth, and sixth years, only a few, but stable, numbers fail every year, and after seven years, the tendency to fail decreases dramatically. The challenges faced by independent coffee shops in the first year are internal and external factors (Douglas et al., 2018). Internal factors consist of managerial, company size, and service. External factors consist of competitive environment, and consumer's satisfaction.

Based on the background and formulation of the problem described, the purpose of this study was to determine the critical success factors for the sustainability of an independent coffee shop in Bogor City.

\section{MATERIAL AND METHODS}

\section{Data Sample}

The data used in this study was primary data and secondary data. Primary data obtained from interviews and questionnaires that have been filled out by respondents. Primary data were information from all independent and dependent variables. Secondary data were obtained from various sources of references or literature in the form of documents relating to the research topic. The qualification of sample was owner or manager of coffee shop that already doing business for one year or more. Based 
on Hair et al. (2011), the population of sample needed for SEM PLS is 10 times of the maximum line pointing at the latent variable. This research outer or inner model maximum line pointing at latent variable was 5 . The minimum sample needed for this research was 50. The total data gathered for this sample was 65 respondents. Total independent coffee shop in Bogor City was 90 stores. It means this research used $72 \%$ of total population as representative. This method was used in Henneberry and Radmehr (2020) research, that using above $60 \%$ of total population of sample is considered enough.

\section{Data Collection Procedures}

Data collection procedures were carried out by giving questionnaires to independent coffee shop owners and managers for sustainability and consumer for satisfaction. In addition, interviews were also conducted with respondents for supplemental data. Data were collected by interview using a questionnaire conducted in person and online.

\section{Data Variable}

Research variables included managerial perspectives, company size, service, product and environment for independent coffee shops and consumer satisfaction with independent coffee shops. The scale used was a Likert scale with five levels, namely (1) strongly disagree, (2) disagree, (3) quite agree, (4) agree, and (5) strongly agree.

Table 1. Research Variables

\begin{tabular}{|c|c|c|}
\hline Latent Variable & Definition & Indicator Variables \\
\hline \multicolumn{3}{|r|}{ Exogenous } \\
\hline \multicolumn{3}{|l|}{ Managerial (X1) } \\
\hline \multirow[t]{2}{*}{$\begin{array}{l}\text { System } \\
\text { Efficiency }\end{array}$} & \multirow[t]{2}{*}{$\begin{array}{l}\text { The ability of managers to } \\
\text { manage systems }\end{array}$} & $\begin{array}{l}\text { 1. Manager has a clear vision or goal in the sustainability } \\
\text { of the coffee shop business }\end{array}$ \\
\hline & & 2. Manager must have a good business plan \\
\hline $\begin{array}{l}\text { Managing } \\
\text { Experience }\end{array}$ & $\begin{array}{l}\text { Manager's experience in } \\
\text { managing a business }\end{array}$ & $\begin{array}{l}\text { 3. Manager must have experience in the appropriate field. } \\
\text { 4. The manager's educational background is important for } \\
\text { the sustainability of an independent coffee shop } \\
\text { 5. Manager must be able to manage the human resources }\end{array}$ \\
\hline Personality & $\begin{array}{l}\text { Manager's Personality } \\
\text { (Klein et al., 2013) }\end{array}$ & $\begin{array}{l}\text { 6. Managers must have attractive personalities. } \\
\text { 7. Managers must be highly motivated. }\end{array}$ \\
\hline Leadership Style & $\begin{array}{l}\text { Leadership style influences } \\
\text { organizational performance } \\
\text { (Klein et al., 2013) }\end{array}$ & $\begin{array}{l}\text { 8. The manager's leadership style must be consistent with } \\
\text { the goals of an independent coffee shop. } \\
\text { 9. Managers must have good leadership skills. }\end{array}$ \\
\hline \multicolumn{3}{|c|}{ Company Size (X2) } \\
\hline \multirow[t]{2}{*}{ Ownership Type } & \multirow{2}{*}{$\begin{array}{l}\text { Independent coffee shop } \\
\text { ownership affects } \\
\text { sustainability (Douglas et } \\
\text { al., 2018) }\end{array}$} & $\begin{array}{l}\text { 1. The number of coffee shop owners will affect the } \\
\text { sustainability of the coffee shop }\end{array}$ \\
\hline & & $\begin{array}{l}\text { 2. Coffee shop owned by one person will last longer than } \\
\text { the multi owners coffee shop. }\end{array}$ \\
\hline Capital & $\begin{array}{l}\text { The size of the capital of } \\
\text { the coffee shop }\end{array}$ & $\begin{array}{l}\text { 3. The amount of capital spent to build a coffee shop } \\
\text { affects the sustainability of the coffee shop } \\
\text { 4. The source of capital obtained affects the sustainability } \\
\text { of the coffee shop. }\end{array}$ \\
\hline \multicolumn{3}{|l|}{ Services (X3) } \\
\hline $\begin{array}{l}\text { Human } \\
\text { Resources }\end{array}$ & $\begin{array}{l}\text { Friendly consumer service } \\
\text { and cleanliness of coffee } \\
\text { shop are the factors of } \\
\text { coffee shop for consumer } \\
\text { (Singh and Saluja, 2013) }\end{array}$ & $\begin{array}{l}\text { 1. The number of employees affects the sustainability of } \\
\text { the coffee shop. } \\
\text { 2. The quality of life of employees affects the } \\
\text { sustainability of the coffee shop. } \\
\text { 3. Waiter's skills in serving skills influence the } \\
\text { sustainability of the coffee shop. } \\
\text { 4. Provide training for employees to influence the } \\
\text { sustainability of the coffee shop. } \\
\text { 5. The speed in providing products has an effect on the } \\
\text { sustainability of the coffee shop. }\end{array}$ \\
\hline Facility & $\begin{array}{l}\text { Facilities are an important } \\
\text { factor in meeting consumer } \\
\text { needs (Yuriansyah, 2013) }\end{array}$ & $\begin{array}{l}\text { 6. Pay attention to unique facilities and are not provided at } \\
\text { other coffee shops. } \\
\text { 7. Providing a comfortable and clean place affects the } \\
\text { sustainability of the coffee shop. }\end{array}$ \\
\hline
\end{tabular}


8. Collaboration with online applications to deliver products directly to consumers has an effect on the sustainability of the coffee shop.

\begin{tabular}{|c|c|c|}
\hline \multicolumn{3}{|c|}{ Environment (Douglas et al., 2018) (X4) } \\
\hline Location & $\begin{array}{l}\text { The choice of coffee shop } \\
\text { location }\end{array}$ & $\begin{array}{l}\text { 1. Stable environment is more influential than a fluctuating } \\
\text { environment on the sustainability of a coffee. }\end{array}$ \\
\hline Competitor & $\begin{array}{l}\text { Competitors of a larger } \\
\text { coffee shop franchise }\end{array}$ & $\begin{array}{l}\text { 2. The number of competitors in the business environment } \\
\text { influences the sustainability of the coffee shop. } \\
\text { 3. Dominant competitor influences the sustainability of the } \\
\text { coffee shop. } \\
\text { 4. Franchise competitors will be harder to deal with than } \\
\text { independent coffee shops. }\end{array}$ \\
\hline \multicolumn{3}{|l|}{ Product (X5) } \\
\hline Product Concept & $\begin{array}{l}\text { Products must have a core } \\
\text { concept of a strong product } \\
\text { definition which is a } \\
\text { representation of the } \\
\text { company's goals }\end{array}$ & $\begin{array}{l}\text { 1. Independent coffee shops must have signature products. } \\
\text { 2. Products sold must be in accordance with the concept of } \\
\text { an independent coffee shop. } \\
\text { 3. Independent coffee shops must sell products with } \\
\text { premium ingredient. } \\
\text { 4. Products must meet the demand of all people. }\end{array}$ \\
\hline $\begin{array}{l}\text { Product } \\
\text { Inovation }\end{array}$ & $\begin{array}{l}\text { Product innovation needs to } \\
\text { be done for sustainability } \\
\text { (Reguia, 2014). }\end{array}$ & $\begin{array}{l}\text { 5. Every coffee shop must have a division to develop } \\
\text { products. } \\
\text { 6. The importance of developing products in accordance } \\
\text { with applicable trends. } \\
\text { 7. Coffee shops must issue new products within a certain } \\
\text { period. }\end{array}$ \\
\hline
\end{tabular}

\section{Endogenous}

Coffee Shop Sustainability (Y1)

The average independent coffee shop is failed in the first year (Douglas et al., 2018).

1. Manager or owner has been managing this coffee shop for more than two years.

2. Manager or owner experiencing an increase in the quality of human resources in the past year.

3. Manager or owner experiencing that the size of his/her coffee shop has grown in the past year.

4. Manager or owner experiencing an increase in services in the past year.

5. Manager or owner experiencing the benefits of coffee shop continues to grow in the past year.

\section{Data Analysis}

The analysis used in this research was descriptive analysis which was an analysis conducted to assess the characteristics of a data. Presentation of the data was assisted by the Rating Scale measurement scale with a score range of 1-5. Respondents' answers to the research statement were grouped into agree and disagree answers. Answers (1) strongly disagree, (2) disagree, and (3) less agree were classified as disagree answers, (4) agree and (5) strongly agree were classified as agreed answers.

Respondents' answers obtained were tested using the validity test and reliability test in advance to measure the validity of the questionnaire to construct research variables. The data is valid if the value of $r$ arithmetic is greater than the value of $r$ tables that depend on the number of samples and benchmarks of tolerated errors $(\alpha)$. The data was processed using the
Structural Equation Modeling (SEM) method. The type of SEM analysis used was Partial Least Square (PLS).

\section{Research Framework}

The research was conducted to analyze the managerial influence, company size, service, and coffee shop environment on the sustainability of an independent coffee shop, and consumer satisfaction with the sustainability of an independent coffee shop. The depiction of discussing conceptual thinking is presented in Figure 3.

\section{Research Design, Location, and Time}

This research used quantitative approach. This research was conducted for 6 months from November 2019 to May 2020 in Bogor City. 


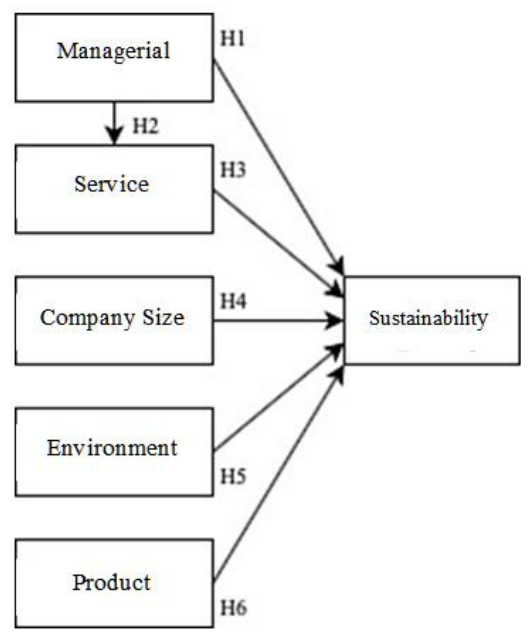

Figure 3. Research framework

H1 : Managerial system is significantly and positively related to sustainability of coffee shops

$\mathrm{H} 2$ : Managerial system is significantly and positively related to services

H3 : Service is significantly and positively related to sustainability of the coffee shop
H4 : Company size is significantly and positively related to sustainability of the coffee shop

H5 : Environment is significantly and positively related to sustainability of the coffee shop

H6 : Products is significantly and positively related to sustainability of coffee shops

\section{RESULTS AND DISCUSSION}

\section{The Characteristic of Respondent}

The respondent characteristic was classified by age, educational degree, job, and the age of coffee shop. Table 2 showed that $72 \%$ respondents have run their business for more than 2 years.

\section{Hypothesis Test}

Based on Table 3, the indicators in the questionnaire in this study was extracted perfectly and have a loading factor value $>0.7$. This showed that the indicators used in this study had a good ability to explain the construct.

Based on Table 4, the cross loading value of each variable was higher than other variable in their respective column. This means each latent variable was unique and valid to use as latent variable.

Table 2. Respondent demographic

\begin{tabular}{lccc}
\hline Characteristic & Category & Total $(\mathbf{n}=\mathbf{6 5})$ & Percentage \\
\hline Age & $19-29$ & 46 & $71 \%$ \\
& $30-39$ & 15 & $23 \%$ \\
Educational Degree & $>40$ & 4 & $6 \%$ \\
& High School & 10 & $15 \%$ \\
& Diploma & 14 & $22 \%$ \\
Job & Undergraduate (S1) & 39 & $60 \%$ \\
& Master/Doctor (S2/S3) & 2 & $3 \%$ \\
& Entrepreneur & 39 & $60 \%$ \\
& Lawyer & 1 & $2 \%$ \\
& Student & 10 & $15 \%$ \\
& Manager & 2 & $3 \%$ \\
& Architect & 1 & $2 \%$ \\
& Employee & 12 & $18 \%$ \\
& $1-2$ & 18 & $28 \%$ \\
& $>2$ & 47 & $72 \%$ \\
\hline
\end{tabular}


Table 3. Outer loading

\begin{tabular}{|c|c|c|c|c|c|c|}
\hline & Sustainability & Service & Environment & Managerial & Product & Company Size \\
\hline KB1 & 0.893 & & & & & \\
\hline KB2 & 0.880 & & & & & \\
\hline KB3 & 0.906 & & & & & \\
\hline KB4 & 0.907 & & & & & \\
\hline KB5 & 0.929 & & & & & \\
\hline KB6 & 0.901 & & & & & \\
\hline KB7 & 0.883 & & & & & \\
\hline KB8 & 0.912 & & & & & \\
\hline LK1 & & & 0.833 & & & \\
\hline LK2 & & & 0.855 & & & \\
\hline LK3 & & & 0.861 & & & \\
\hline LK4 & & & 0.901 & & & \\
\hline LK5 & & & 0.837 & & & \\
\hline LY1 & & 0.930 & & & & \\
\hline LY2 & & 0.882 & & & & \\
\hline LY3 & & 0.927 & & & & \\
\hline LY4 & & 0.951 & & & & \\
\hline LY5 & & 0.879 & & & & \\
\hline LY6 & & 0.843 & & & & \\
\hline LY7 & & 0.874 & & & & \\
\hline LY8 & & 0.876 & & & & \\
\hline MN1 & & & & 0.879 & & \\
\hline MN2 & & & & 0.913 & & \\
\hline MN3 & & & & 0.835 & & \\
\hline MN4 & & & & 0.871 & & \\
\hline MN5 & & & & 0.813 & & \\
\hline MN6 & & & & 0.900 & & \\
\hline MN7 & & & & 0.907 & & \\
\hline MN8 & & & & 0.889 & & \\
\hline MN9 & & & & 0.891 & & \\
\hline PR1 & & & & & 0.922 & \\
\hline PR2 & & & & & 0.876 & \\
\hline PR3 & & & & & 0.893 & \\
\hline PR4 & & & & & 0.891 & \\
\hline PR5 & & & & & 0.833 & \\
\hline PR6 & & & & & 0.873 & \\
\hline PR7 & & & & & 0.893 & \\
\hline UP1 & & & & & & 0.845 \\
\hline UP2 & & & & & & 0.783 \\
\hline UP3 & & & & & & 0.851 \\
\hline UP4 & & & & & & 0.842 \\
\hline
\end{tabular}


Table 4. Cross loading

\begin{tabular}{|c|c|c|c|c|c|c|}
\hline & Sustain ability & Service & Environment & Managerial & Product & Company Size \\
\hline KB1 & 0.893 & 0.785 & 0.722 & 0.752 & 0.720 & 0.669 \\
\hline $\mathrm{KB} 2$ & 0.880 & 0.726 & 0.628 & 0.724 & 0.670 & 0.528 \\
\hline KB3 & 0.906 & 0.767 & 0.630 & 0.819 & 0.782 & 0.609 \\
\hline KB4 & 0.907 & 0.705 & 0.597 & 0.794 & 0.745 & 0.604 \\
\hline KB5 & 0.929 & 0.773 & 0.685 & 0.789 & 0.755 & 0.634 \\
\hline KB6 & 0.901 & 0.697 & 0.647 & 0.680 & 0.679 & 0.549 \\
\hline KB7 & 0.883 & 0.755 & 0.656 & 0.707 & 0.686 & 0.572 \\
\hline KB8 & 0.912 & 0.762 & 0.610 & 0.746 & 0.701 & 0.603 \\
\hline LK1 & 0.567 & 0.664 & 0.833 & 0.620 & 0.495 & 0.588 \\
\hline LK2 & 0.665 & 0.639 & 0.855 & 0.680 & 0.547 & 0.578 \\
\hline LK3 & 0.579 & 0.657 & 0.861 & 0.693 & 0.558 & 0.539 \\
\hline LK4 & 0.679 & 0.661 & 0.901 & 0.682 & 0.597 & 0.572 \\
\hline LK5 & 0.572 & 0.535 & 0.837 & 0.584 & 0.535 & 0.580 \\
\hline LY1 & 0.756 & 0.930 & 0.683 & 0.695 & 0.593 & 0.641 \\
\hline LY2 & 0.775 & 0.882 & 0.657 & 0.749 & 0.674 & 0.656 \\
\hline LY3 & 0.800 & 0.927 & 0.673 & 0.695 & 0.629 & 0.658 \\
\hline LY4 & 0.803 & 0.951 & 0.666 & 0.699 & 0.654 & 0.708 \\
\hline LY5 & 0.742 & 0.879 & 0.608 & 0.643 & 0.563 & 0.548 \\
\hline LY6 & 0.679 & 0.843 & 0.689 & 0.701 & 0.703 & 0.542 \\
\hline LY7 & 0.663 & 0.874 & 0.623 & 0.603 & 0.671 & 0.585 \\
\hline LY8 & 0.702 & 0.876 & 0.677 & 0.616 & 0.639 & 0.617 \\
\hline MN1 & 0.732 & 0.619 & 0.659 & 0.879 & 0.673 & 0.521 \\
\hline MN2 & 0.769 & 0.681 & 0.649 & 0.913 & 0.690 & 0.536 \\
\hline MN3 & 0.699 & 0.637 & 0.675 & 0.835 & 0.631 & 0.557 \\
\hline MN4 & 0.734 & 0.708 & 0.786 & 0.871 & 0.639 & 0.637 \\
\hline MN5 & 0.687 & 0.619 & 0.643 & 0.813 & 0.635 & 0.571 \\
\hline MN6 & 0.730 & 0.679 & 0.628 & 0.900 & 0.650 & 0.530 \\
\hline MN7 & 0.708 & 0.637 & 0.691 & 0.907 & 0.598 & 0.537 \\
\hline MN8 & 0.753 & 0.664 & 0.623 & 0.889 & 0.663 & 0.580 \\
\hline MN9 & 0.781 & 0.719 & 0.663 & 0.891 & 0.648 & 0.560 \\
\hline PR1 & 0.719 & 0.633 & 0.529 & 0.680 & 0.922 & 0.582 \\
\hline PR2 & 0.727 & 0.737 & 0.593 & 0.616 & 0.876 & 0.629 \\
\hline PR3 & 0.743 & 0.643 & 0.572 & 0.675 & 0.893 & 0.611 \\
\hline PR4 & 0.680 & 0.601 & 0.565 & 0.674 & 0.891 & 0.529 \\
\hline PR5 & 0.673 & 0.619 & 0.589 & 0.665 & 0.833 & 0.523 \\
\hline PR6 & 0.728 & 0.598 & 0.564 & 0.652 & 0.873 & 0.569 \\
\hline PR7 & 0.646 & 0.577 & 0.534 & 0.593 & 0.893 & 0.545 \\
\hline UP1 & 0.583 & 0.711 & 0.577 & 0.570 & 0.599 & 0.845 \\
\hline UP2 & 0.506 & 0.386 & 0.524 & 0.523 & 0.476 & 0.783 \\
\hline UP3 & 0.441 & 0.471 & 0.491 & 0.425 & 0.428 & 0.851 \\
\hline UP4 & 0.633 & 0.678 & 0.597 & 0.568 & 0.606 & 0.842 \\
\hline
\end{tabular}


Table 6 showed that every variable in this research was valid. The variables were reliable because the composite reliability, Cronbach's alpha, and AVE value were greater than 0.7, 0.6, and 0.5, respectively.

Table 7 showed that all variables in this study were fit, shown by an SRMR value that was smaller than 0.1. Meanwhile, the values of d_ULS, d_G1, and d_G2 were more than 0.5 (Table 8).

\section{Relation between Managerial System and Coffee Shop Sustainability}

The result of this research showed that managerial system was an important factor in coffee shop sustainability. The statistic result showed that managerial system was significantly affecting in coffee shop services $(\mathrm{p}<0.05)$. Original sample (path coefficient) showed the value of 0.758 . The result also showed that managerial system was significantly affecting in coffee shop sustainability $(\mathrm{p}<0.05)$. Original sample (path coefficient) showed the value of 0.358 . The result showed that managerial system was affecting coffee shop services and sustainability positively.

Leadership style affected organizational culture which will ultimately affect organizational performance. Consider leadership as a pattern associated with managerial behavior, designed to integrate organizational or personal interests and effects to achieve certain goals (Mitonga and Coetzee, 2012).

Table 6. Construct reliability and validity

\begin{tabular}{lcccc}
\hline & $\begin{array}{c}\text { Cronbach's } \\
\text { Alpha }\end{array}$ & rho_A & $\begin{array}{c}\text { Composite } \\
\text { Reliability }\end{array}$ & $\begin{array}{c}\text { Average Variance } \\
\text { Extracted (AVE) }\end{array}$ \\
\hline Sustainability & 0.967 & 0.968 & 0.972 & 0.813 \\
Service & 0.965 & 0.966 & 0.970 & 0.803 \\
Environment & 0.910 & 0.915 & 0.933 & 0.736 \\
Managerial & 0.963 & 0.964 & 0.968 & 0.771 \\
Product & 0.953 & 0.954 & 0.961 & 0.780 \\
Company Size & 0.852 & 0.862 & 0.899 & 0.690 \\
\hline
\end{tabular}

Table 7. Goodness of fit

\begin{tabular}{lcc}
\hline & Saturated Model & Estimated Model \\
\hline SRMR & 0.062 & 0.081 \\
d_ULS & 3.298 & 5.718 \\
d_G1 & 7.331 & 7.489 \\
d_G2 & 5.835 & 6.010 \\
Chi-Square & 1401.50 & 1416.60 \\
NFI & 0.664 & 0.661 \\
\hline
\end{tabular}

Table 8. Path coefficient

\begin{tabular}{lccccc}
\hline \multicolumn{1}{c}{$\begin{array}{c}\text { Correlating } \\
\text { Variables }\end{array}$} & $\begin{array}{c}\text { Original } \\
\text { Sample } \\
(\mathbf{O})\end{array}$ & $\begin{array}{c}\text { Sample } \\
\text { Mean } \\
(\mathbf{M})\end{array}$ & $\begin{array}{c}\text { Standard } \\
\text { Deviation } \\
(\text { STDEV) }\end{array}$ & $\begin{array}{c}\text { T Statistics } \\
(\mid \mathbf{O} / \text { STDEV })\end{array}$ & P Values \\
\hline $\begin{array}{l}\text { Service -> } \\
\text { Sustainability }\end{array}$ & 0.353 & 0.348 & 0.145 & 2.431 & 0.015 \\
$\begin{array}{l}\text { Environment -> } \\
\text { Sustainability }\end{array}$ & 0.004 & 0.015 & 0.115 & 0.035 & 0.972 \\
$\begin{array}{l}\text { Managerial -> } \\
\text { Sustainability }\end{array}$ & 0.358 & 0.337 & 0.173 & 2.067 & 0.039 \\
$\begin{array}{l}\text { Managerial -> Service } \\
\text { Product -> }\end{array}$ & 0.756 & 0.751 & 0.094 & 8.056 & 0.000 \\
$\begin{array}{l}\text { Sustainability } \\
\text { Company Size -> }\end{array}$ & 0.270 & 0.277 & 0.126 & 2.139 & 0.033 \\
Sustainability & 0.013 & 0.023 & 0.106 & 0.121 & 0.904 \\
\hline
\end{tabular}




\section{Relation between Services and Coffee Shop Sustainability}

The result of this research showed a relation between services and coffee shop sustainability. Statistical test results showed that service had a significant effect on the sustainability of coffee shops because the $p$ value was $0.015(p>0.05)$. The Original Sample (Path Coefficient) value indicated the value of 0.353 . This means it positively affects coffee shop services. Based on respondents' experience, human resources (employees) were one of the import indicators owned by coffee shop owners or managers. Employers needed to provide their employees with appropriate training, specifically in their production skills and services. The quality of life and the environment of employees were equally important for employers. Respondents fear that poor quality of life and employee environment would reduce their performance in production and service.

The important factors that contribute to business success are training, high-quality staff retention, the prevalence of good products, optimal service and time in connecting them to the market as well as excellent relationships with consumers and top managers with quality good leadership (Teng et al., 2011). No less important factors to consider after the service and product value regarding services (Yuriansyah, 2013). Facilities in business must always consider what is or is related to what is received by consumers, because consumers consider the company based on what they get after use (Yuriansyah, 2013).

\section{Relation between Environment and Coffee Shop Sustainability}

The results of this research indicated that environmental research did not affect the sustainability of the coffee shop. Statistical analysis of the data showed a value of $0.972(p>0.05)$. The Original Sample Value (Path coefficient) of 0.004 indicated a positive direction. The environment did not affect the sustainability of the coffee shop. Respondents said that if there was a coffee shop that offers a good atmosphere and facilities, consumers will give their coffee shop back.

Coffee shop owners and managers were not worried. The existence of promotions made their shops more creative in making new innovation products. This was very important. This disputes the general perspective that location and perspective will adversely affect business.

\section{Relation between Company Size and Coffee Shop Sustainability}

The results of this research indicated that the size of the company did not affect the sustainability of the coffee shop. Statistical analysis of the data showed a value of 0.904 ( $p>0.05)$. The value of Original Sample (Path Coefficient) was 0.013. This showed that company size positively influences store sustainability.

Coffee shop ownership did not affect the sustainability of the coffee shop. The capital spent to build a coffee shop did not affect its sustainability. The value of capital was one of the important factors in building a business, but it did not affect sustainability because the most important aspect was the coffee shop managerial system. However, the source of capital affected the sustainability of the coffee shop because it influenced the policy of the owner or manager to run their business.

\section{Relation between Product and Coffee Shop Sustainability}

Innovation of product was important aspect for coffee shop sustainability. Independent coffee shop must have their own signature product that specialized them from other coffee shop. Their signature products attracted their consumers for revisit their shop.

The signature product production needs to aim the right market segmentation and circumstances. For example in 2020 when Covid-19 pandemic happened, coffee shop needs to innovate their product. Independent coffee shop tends to giving promotion for their take away product or make product with health benefit.

The existence of a strong product concept, the product also needs to innovate for product sustainability (Reguia, 2014). The product innovation is the introduction and development of a new product and will be made different from before with more emphasis on quality. Product innovation is needed by companies to survive the competitive pressures, change of tastes and preferences, short product life cycles, technological advances or obsolete, various patterns of demand, and consumer specific requirements (Kanagal, 2015). The making of product innovation, it is necessary to pay attention to market orientation because knowledge of market orientation is the key to the success of product innovation (Wiwoho, 2012).

Table 9. Median relation

\begin{tabular}{lccccc}
\hline & $\begin{array}{c}\text { Original } \\
\text { Sample (O) }\end{array}$ & $\begin{array}{c}\text { Sample } \\
\text { Mean (M) }\end{array}$ & $\begin{array}{c}\text { Standard Deviation } \\
\text { (STDEV) }\end{array}$ & $\begin{array}{c}\text { T Statistics } \\
(\mid \mathbf{O} / \text { STDEV|) }\end{array}$ & P Values \\
\hline $\begin{array}{l}\text { Managerial -> } \\
\begin{array}{l}\text { Service -> } \\
\text { Sustainability }\end{array}\end{array}$ & 0.267 & 0.264 & 0.122 & 2.187 & 0.029 \\
\hline
\end{tabular}


Tabel 10. Result of questionnaire from the owner or manager of independent coffee shop

\begin{tabular}{clcc}
\hline Indicator Symbol & \multicolumn{1}{c}{ Statement } & Agree & Disagree \\
\hline SB1 & Respondent already run their business for more than 2 years & 47 & 18 \\
SB2 & Respondent experiencing improvement in managerial system & 45 & 20 \\
SB3 & Respondent experiencing improvement in human resources & 49 & 16 \\
SB4 & Respondent experiencing the expansion in their business size & 42 & 23 \\
SB5 & Respondent experiencing improvement in their service. & 47 & 18 \\
SB6 & Respondent experiencing increase in their new consumer. & 45 & 20 \\
SB7 & Respondent experiencing increase in profit. & 43 & 22 \\
SB8 & Respondent experiencing increase in facility and inventory in their & 44 & 21 \\
& shop. & & \\
\hline
\end{tabular}

Service mediated the relationship between Managerial and Coffee Shop Sustainability because the $\mathrm{p}$ value was 0.029 or less than 0.05 . The Original Sample (Path Coefficient) value of 0.267 indicated the direction of the positive relationship.

\section{Sustainability of Coffee Shop}

The sustainability of independent coffee shop in Bogor City was observed using eight indicators. Table 10 showed that $69 \%$ of respondents experienced an increase in their coffee shop managerial system, $31 \%$ of respondents did not experience an improvement in their managerial system due to internal problems in the coffee shop. $75 \%$ of respondents experienced an increase in their human resources quality, $25 \%$ did not experience an increase in their human resources quality due to internal problems such as employee commitment and the trust of coffee shop owners towards their employees. $72 \%$ of respondents agreed that their coffee shop service has improved. $65 \%$ of respondents experienced an increase in the size of their business. $69 \%$ of respondents agreed their new consumers increased from year to year. $66 \%$ of respondents have increased profits every year. $68 \%$ of respondents experienced an increase in their facilities and inventory. Coffee shop owners and managers, who have been in business for more than a year, feel the coffee shop that has been managed has increased. They experienced an increase in service from year to year because the owners always hold training for employees in a certain period in order to improve the quality of employees and increase the number of coffee shop consumers. Coffee shop owners felt that their coffee shop was getting more advanced in terms of their facilities such as increasingly attractive places, supporting facilities, and sophisticated equipment.

\section{CONCLUSIONS AND RECOMMENDATION}

\section{Conclusions}

The result of this research showed that sustainability of independent coffee shop in Bogor
City is affected by three factors, namely managerial, service, and product. Factors that do not affect sustainability of independent coffee shop are company size and the environment. The managerial factor has the most dominant latent variable on the sustainability of independent coffee shops in Bogor, namely the leadership style. The service factor has the most important latent variable on the sustainability of independent coffee shops, namely human resources. The product factor has the latent variable that is most important for the sustainability of an independent coffee shop in Bogor City, which is the product signature. Independent coffee shop owners and managers in the city of Bogor is the increase in services.

\section{Recommendation}

This research needs more investigation about sustainability of coffee shops during the Covid-19 pandemic.

\section{REFERENCES}

BPS. 2018. Indonesian Coffee Statistic. Jakarta: BPS Douglas J, Douglas A, Cano M, dan Moyes D. 2018. Investigating the success of independent coffee shops and cafes in the UK: Findings from a pilot study. Excellent in Services. 21(1): 297-310.

Hair JF, Ringle CM, and Sarstedt M. 2011. PLSSEM: indeed a silver bullet. Journal Marketing Theory and Practice. 19 (2): 139151.

Hennenberry SR and Radmehr R. 2020. Quantifying impacts of internships in an international agriculture degree program. PLoS ONE. 15(8): 1-28.

Higdon B. 2016. Strategies Independen Coffee Shop Owners Require to Survive Beyond Five Years. Washington (USA): Walden University.

ICO. 2019. Trade Statistics, International Coffee Organization (ICO). London (UK). Diakses : 18 November 2019. 
http://www.ico.org/trade_statistics.asp?section= Statistics

Irjayanti M and Aziz AM. 2012. Barrier factors and potential solutions for Indonesian SMEs. Procedia Economics and Finance. 4: 3-12.

Kanagal NB. 2015. Innovation and product innovation in marketing strategy. Journal Management and Marketing Research. 18(2) : $1-25$.

Kato M, Okamuro H, and Honjo Y. 2015. Does founders' human capital matter for innovation? Evidence from Japanese start-ups. Journal Small Business Management. 53(1): 114-128.

Klein AS, Cooke RA, and Wallis J. 2013. The Impact of leadership styles on organizational culture and firm effectiveness: An empirical study. Journal Management \& Organization. 19(3) : 241-254.

Mazzarol T, Clark DN, and Reboud S. 2014. Strategy in action: case studies of strategy, planning and innovation in Australian SMEs. Small Enterprise Research. 21(1) : 54-71

Mitonga-Monga J, dan Coetzee M. 2012. Perceived leadership style and employee participation in a manufacturing company in the democratic republic of Congo. African Journal Business Management. 6(15): 5389-5398.

Nadiri H and Gunay NG. 2013. An empirical study to diagnose the outcome of customers experience in trendy coffee shop. Journal Business Economics and Management 14 (1) :22-53.

Rahayu R, and Day J. 2015. Determinant factors of ecommerce adoption by SMEs in developing country: evidence from Indonesia. Procedia Social and Behavioral Sciences 195: 142-150.
Ramdhani F and Hardjomidjojo H. 2019. Analysis of medium small business performance in the City of Bogor. Journal Engineering and Agroindustry Management. 7: 133-152

Reguia C. 2014. Product innovation and the competitive advantage. European Scientific Journal 1(5): 140-157.

Singh S, and Saluja D. 2013. Customer Satisfaction Study of Barista Coffee. India : New Delhi

Susanty A, and Kenny E. 2015. The relationship between brand equity, customer satisfaction, and brand loyalty on coffee shop: Study of Excelso and Starbucks. Asean Marketing Journal. 7(1): 14-27.

Tarute A, and Gatautis R. 2014. ICT impact on SMEs performance. Procedia-Social and Behavioural Sciences. 110: 1218-1225.

Teng HSS, Bhatia GS, and Anwar S. 2011. A success versus failure prediction model for small businesses in Singapore. American Journal Business. 26(1): 50-64.

Wiwoho G. 2012. Analisis pengaruh orientasi pasar, orientasi pembelajaran terhadap inovasi produk dan kinerja pemasaran (Studi pada sentra industri kecil rumah tangga Kerajinan Anyaman Pandan di Desa Grenggeng, Kecamatan Karanganyar, Kabupaten Kebumen). Jurnal Manajemen. 12 (2): 34-50.

Yuriansyah AL. 2013. Persepsi tentang kualitas pelayanan, nilai produk dan fasilitas terhadap kepuasan konsumen. Manajemen Analisis Jurnal. 2 (1): 9-14.

Zuhriyah DA. 2019. Industri coffee shop ditaksir tumbuh 20\% tahun ini. Diakses : 14 Desember 2019

Diakses dari:https://ekonomi.bisnis.com/read/ 20190822/12/1139918 